\title{
ECONOMIC AND CULTURAL IMPACT OF TOURISM MARKETING1
}

This paper investigates how to model causes and measure the consequences of cultural tourism by evaluating the economic and cultural impacts caused by cultural tourist attractions. The paper introduces a novel approach both to building the comprehensive literature review and constructing the methodology and the toolbox for investigating the economic and cultural impacts of tourism marketing. The results and findings of this paper might be useful for stakeholders, policy-makers and tourism professionals both in public and private spheres. Moreover, the paper sheds some light on the role of innovations in enhancing the economic and cultural impact of tourism in tourism marketing. These findings might be of some interest both for tourism marketing professionals and marketologists pursuing new strategies for increasing the impact of tourism marketing in old and new destinations.

Keywords: tourism marketing, cultural tourism, innovations, cultural heritage, tourism economics.

DOI: 10.21272/mmi.2017.3-05

Introduction. Tourism is perhaps the most influential industry in the world economy. According to the World Travel and the Tourism Council [1], even during the recession year of 2009, the Travel and Tourism industry still employed over 235 million people worldwide, which accounted for $8.2 \%$ of all employment and generated $9.4 \%$ of world GDP. This is expected to rise to 279.3 million jobs by 2016 [2].

No matter how culture is defined, cultural tourism is an important part of tourism [3]. WTO and ETC (2005) indicate $20 \%$ of city tourists' prime motivator for travelling is culture, while statistics from the World Tourism Organization put this figure at 40\% [4]. The Travel Industry Association of America (TIA) has estimated that two-thirds of U.S adults visit a cultural or heritage site or attraction when they travel [5].

Although cultural tourists make up a significant proportion of tourists in the tourism industry, the same can be said about many other types of tourism [6; 7]. The literature makes many distinctions between tourism types. Some of these are generally regarded as types of cultural tourism, others are not; probably dark tourism is and beach tourism is not. But what is about city tourism, event tourism and gastro-tourism? Among all these types, cultural tourism has a specific character that is absent from some tourism types. A tourist who spends a day on a beach probably enjoys the experience. In just the same way, a tourist who visits an art gallery probably enjoys that. However, these examples are different to one another because the visitor to the gallery may use the experience to change his point of view, while the beach tourist is unlikely to find this. Both tourists can gain utility from the experience at the time, but the visitor to the gallery may take away with him something of long lasting or even permanent value.

The main objective of paper is to gain a better understanding of tourism marketing and specifically cultural tourism. In order to do so, a small number of cultural tourist typologies have been developed. A cultural tourist typology is a type of classification which separates all cultural tourists into a fixed number of groups, according to their different characters on certain aspects (e.g. choices of destination, travelling behaviour, motivations, age, gender, occupation, etc.) A key feature is that every cultural tourist fits into one and only one of the groups and such a typology is taxonomy.

A well-designed tourist typology can help the government and the tourism industry to make crucial decisions on investment, product development, promotion, pricing and so on, because a tourist typology

\footnotetext{
${ }^{1}$ This research was supported by the Foundation for Outstanding Young Scientist in Shandong Province ( Grant No. 2013BSE27104) \& the Foundation of Shandong University Humanities and Social Sciences Team Project (Grant No. IFYT15004).
} 
can enhance the decision-makers' understanding of tourists' behaviour and the segmentations in the tourism market, and possibility help them with forecasting future trends [8; 9].

Analysis of recent research and publications. The majority of typologies are focused on classifying tourists in general. However, [10] designed a cultural tourist typology that classified cultural tourists into five different types through two dimensions: the importance of cultural tourism in tourists' decision to visit a destination; and the depth of experience gained.

Among all tourist typologies, no real analysis of tourists' behaviour has been done to support or explain the reasons behind why tourists should be classified into a certain number of different groups $[11 ; 12 ; 13]$. It has been said that some of the research typologies (not necessarily solely used for tourism research) are over-descriptive, and do not help marketers and researchers gain any deeper understanding of tourist behaviour [14; 15].

One obvious consequence of cultural tourism is the economic impact. According to [5], cultural tourism brings significant economic benefit to museums and heritage sites; therefore, accessing the actual economic impact caused by the attraction and investigating ways to increase the volume of tourists visiting is becoming crucially important. The WTO and ETC [16] also stress that more in-depth and comparable data regarding cultural tourism is needed in future cultural tourism research to gain a better understanding and to react to the fast-changing tourism market.

Another equally important consequence is the cultural impact of cultural tourism, which is one of the principal concerns of this research. Matarasso [17] suggests 50 potential benefits visitors can gain from participating in the arts, for example:

- increase people's confidence and sense of self-worth,

- give people influence over how they are seen by others,

- stimulate interest and confidence in the arts,

- develop pride in local traditions and cultures,

- provide a unique and deep source of enjoyment, etc.

Since art is a part of culture, all of the 50 benefits of arts can be seen as examples of cultural impact. In the modern tourism industry, the real cultural tourists are the people who can really sublimate the physical cultural capital to the intangible cultural capital (i.e. gaining cultural value) after their cultural consumptions.

Due to the difficulty of quantifying cultural impact, only very limited empirical evaluation of sociocultural impact can be found in the literature [18; 19]. Hence, more explorations need to be done on understanding the value of culture and methods can be used to measure and contrast the cultural impact in different areas [20].

Economic impact and cultural impact are two different aspects of the impact a cultural tourism visit has. Different attractions can be expected to give different combinations of economic and cultural impact. The space in which the economic and cultural impacts lie is referred to here as the 'impact space'. The position of an attraction in impact space shows the economic and cultural consequences of visits to the attraction.

Economic and cultural impacts have some things in common. If an attraction is very important in attracting tourists to its destination, it will tend to have a large economic impact and a large cultural impact. On the other hand, if visits to an attraction are incidental to visits to the destination, then the attraction may tend to have a small economic impact and a small cultural impact (e.g. Charles Dickens' House in London). However, the proportion of cultural and economic impacts depends on what the attraction is. One attraction may have a bigger cultural impact than another but a smaller economic impact (i.e. the British Museum vs. the Galleries of Justice). Which of these is preferable depends on the priorities that policy puts on culture and the economy.

From this it becomes obvious that the economic impact of an attraction is not the only impact 
caused. Only supporting the attractions that cost less than the demonstrable economic impact would be socially inefficient, as this would mean that policy makers would be failing to support attractions where the cultural impact provides good value for money. In other words, without considering the cultural impact, the total impact of cultural attractions would be underestimated.

Many cultural attractions are funded or subsidised by the public sector. The cost of creating and maintaining an attraction is clear, but the returns from that attraction are less so. The literature suggests that an accurate assessment of the returns must take into account not only the economic, but also the cultural impact. The same rule applies to possible changes in attractions. A change in an attraction may affect the economic impact, the cultural impact or both, with both being able to change independent of the other. However, all changes involve costs, so an accurate assessment of whether the change is worthwhile should take not only the change in economic impact into account, but also the change in cultural impact.

These questions are of immediate importance because of current cuts in funding. However, they will always be important in terms of the reduction or expansion in government spending, in order for policy to be efficient. Assuming the government needs to cut or spend 10 million pounds on cultural attractions in the tourism industry, how they should spend or cut it? In either case, understanding the causes and consequences of cultural tourism is of key importance.

Basic materials. In the $21^{\text {st }}$ century, the tourism industry is changing unpredictably in a turbulent environment [21], and the tourism industry comprises all businesses which provide goods or services for leisure and pleasure activities for people who are away from home [22]. In 1991, at the WTO conference on tourism statistics, the term 'tourism' was defined as 'the activities of a person travelling outside his/her usual environment for less than a specified period of time and whose main purpose of travel is other than exercised of an activity remunerated from the place visited' [23]. Tourism travel is a relatively recent phenomenon indicates the idea of leaving one's home and workplace in order to seek and gain pleasures is a popular way of enjoying one's life. Before the 19th century, apart from the upper classes, very few people had the opportunity to travel to destinations they desired to, especially for non-work [23; 24].

Many researchers say that the international tourism industry has changed and developed considerably during the past two decades. There are new scientific tools and approaches applied to researching this changed industry that empliy the tools from other areas of research $[25 ; 26]$. Increasingly, many people are willing to spend money on holidays and travelling and, therefore, new patterns of tourism consumption and production have emerged. According to the statistics from the [2], the travel and tourism economy supports 234.3 million jobs worldwide. This represents $8.7 \%$ of total employment or 1 in every 11.5 jobs, and this will rise to 279.3 million travel and tourism related jobs by 2016 [2].

As tourism is becoming one of the largest and fastest growing industries in the world, and one of the biggest income generators, tourists are demanding more than before, so stakeholders need to diversify promotion of the industry, and also make their products more distinctive. New types of tourism are becoming more flexible, sustainable and individual-oriented, because people like to feel rewarded and enriched, and to gain learning experiences.

With the tourism industry changing and developing dramatically, Poon [27] coined the term 'new tourism' which includes the following features. The holiday is getting more flexible: because of economies of scale, tourists can travel to places at competitive prices. Tourism related services are marketed, produced and tailored for individuals, according to their different needs, incomes, time constraints and travel interests. Holidays are consumed by more experienced tourists, and they are also more educated, more destination-oriented, more independent, more flexible and more environmentallyfriendly. The environment and culture of the destination are considered as key parts of the holiday experience by consumers of new tourism. The emergence of the new tourism industry requires stakeholders and marketers to tailor tourism packages, promoting cultural tourism sites from different 
angles at the right place, to the right tourists, since the mass marketing strategy should not be the dominant one anymore. Krippendorf [28] also stresses that tourists are getting more determined to gain satisfaction from all different areas in their life, and in order to drive them away from a fulfilling job and joyful life, the travelling must provide something extra or unique to attract the potential tourists.

Swarbrooke and Horner (2006) stated the most popular debate in tourism literature during the last two decades is how to define tourists and travellers. Horner and Swarbrooke [29] stress those two terms represent two different types of visitors, and they define a tourist as someone who buys a package from a travel agency, and a traveller as a person who makes his/her own travel itinerary and bookings for a holiday. Horner and Swarbrooke [29] say that travellers are increasing in numbers relative to tourists and more people still prefer to be seen as travellers rather than tourists, even if they buy tourist packages. Cooper and Hall (2008) points out that the contemporary tourists are demanding, empowered, knowledgeable and intelligent. They prefer to have more control rather than to be passive in the marketing process.

The tourism industry as a whole is comprised of many sub-types of tourism including cultural tourism, business tourism, health tourism, social tourism, educational tourism, religious tourism, activity tourism, etc. Although the method of dividing them can be subjective, the beneficial side of separating tourism into different types is that more focused marketing strategies can be developed for each specific type of tourism industry (Swarbrooke and Horner, 2006). According to statistics from the World Tourism Organization, nearly $40 \%$ of all tourist trips are related to cultural tourism [4]. Moreover, the Travel Industry Association of America has also estimated that two-thirds of U.S adults visit a cultural or heritage site of attraction when they travel [5].

In the last two decades, many studies have classified cultural tourists using data in empirical studies. Disposable income, level of education and socio-economic status are the factors that have been widely used to explain cultural tourists' behaviour. Many researchers identify educational background is one of the crucial determining elements of cultural tourism participation $[4 ; 5 ; 30]$ reports that a study of European museums shows that tourists' level of education has more influence than their income on their attendance at museums. Through a study of cultural tourists in Germany, Roth and Langemeyer [30] also found that the highly-educated tourist group is the most highly represented one among all different types of cultural tourists. Silberberg [5] also indicates the higher education level and income the person has, the more likely he/she is to be more interested in culture. Strielkowski [31] studied cultural tourism on an example of film-induced tourism in Prague based in the Hollywood-like special forces-type Operation Anthropoid events that took place in 1942.

McKercher and du Cros [32] take the view that in deciding whether to identify a tourist as a cultural tourist; 'centrality' plays a critical role, meaning (essentially) whether or not a cultural element is central to the purpose of the visit. For instance, should a VFR (visiting friends and relatives) tourist who visited a cultural heritage attraction while on the trip be classified as a cultural tourist? Should one label as a cultural tourist a person who was on a business trip but went to a non-work related cultural event before he returned home? It is very hard to give a definite answer, since it is not certain whether those visitors travelled to a city or stayed longer in a city because that place has more culture attractions/events or due to visitors having more time to spend in that city, so they visited culture-related places. In reality, this can happen either way. McKercher and du Cros [32] clearly state that to give an accurate answer to the above questions, the centrality of their visits need to be resolved first, and they define a cultural tourist as someone who visits a cultural related attraction (e.g. museum, art gallery, historic site) or attends a cultural event or festival at some point during their visits, but disregard his/her primary reason to travel to that destination.

As for marketing purposes, the timing of the decision-making to visit a particular cultural attraction has very interesting and crucial results, since it indicates when and where the potential consumer should be reached and promoted. The ATLAS results show the majority of cultural tourists decide where they 
want to visit before leaving home; whereas $30 \%$ of visitors decide when they arrive at the destination. Moreover, the ATLAS results also indicate people who plan their trips before arriving at the destination were significantly older and less well-educated, but with higher incomes. The younger and the more highly educated tourists were more likely to wait until they arrived at the destination, and then choose which attractions to visit [16].

Main results. Assessing the cultural impact of tourism is as important as evaluating the economic impact caused by tourism, but due to the difficulty of quantifying it only very limited empirical studies of socio-cultural impact evaluations can be found in the literature [33; 18].

Table 1 - The Appropriateness of Different Methods for Assessing (own results based on [34])

\begin{tabular}{|c|c|c|c|c|}
\hline Method & Past & Present & Future & Remarks \\
\hline Intervention analysis & $\bullet$ & & & Requires historical time series data \\
\hline Causal analysis & $\bullet$ & $\bullet$ & & Must be done at the time of an event \\
\hline CGE & $\bullet$ & $\bullet$ & $\bullet$ & Requires detailed quantitative knowledge of economic system \\
\hline Conjoint analysis & & & $\bullet$ & Requires extensive survey information \\
\hline
\end{tabular}

Small at al. [33] argue that even if festivals and events are making positive economic impacts, the social-cultural impacts of the events should still be evaluated because, if the latter has been constantly negative, it can demolish the economic benefit to the local economy in the long run. Getz [35] and Douglas et al. [36] suggest stakeholders should not make the cultural attractions too commercialized in order to attract more visitors, as the factors such as culture preservation and cultural influence should also be taken into consideration, otherwise the negative cultural impact can destroy the image and reputation of an attraction or a destination in the long term.

The cultural impact of tourism can be evaluated from two different angles: the local residents and tourist visitors [33]. As for the local residents' aspects, researchers hold two different attitudes based on the contrasting results from their studies. Brougham and Butler [37] believe the closer the locals live to or get involved in the tourist activities, the more negative the perception they would have regarding the cultural impact of tourism. In contrast, several research studies [38; 39; 40] found totally opposite results to the earlier ones. Those converse results from the previous studies indicate that whether the locals' perception of cultural tourism impact is negative or positive may also link to the type of tourist activities they get involved in, and also the community itself [33].

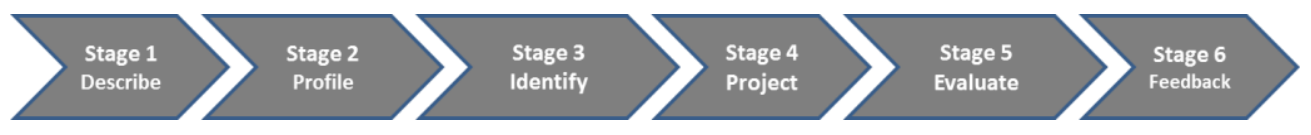

Figure 1 - Social Impact Evaluation Framework (own results based on [33])

In the recent years, researchers started finding methods to measure socio-cultural impact. Moreover, Small et al. [33] designed a Social Impact Evaluation (SIE) framework (Figure 1 above) for evaluating socio-cultural impacts caused by festivals or events. This six-stage framework was designed by integrating the foregoing socio-cultural impact assessment models together including description, profiling, identification, projection, evaluation and feedback. The framework seems to be useful in conducing the analysis and the evaluation just as the one carried out in this study.

Conclusions and discussions. This paper provided an overview of the main theoretical and empirical concepts as well as the overview of the relevant literature that is related to the economic and cultural impacts of tourism marketing. The paper scrutinized and criticized the state of the (cultural) tourist typologies, and the methods that have been used in previous studies for evaluating the economic 
and cultural impacts of (cultural) tourism. All of the above helps to place the research issues of this study in the context of the current tourism research perspective. As discussed above, there is a considerable debate with respect to tourist typologies and their practical application. The reason that it is important to acknowledge this is that a well-designed tourist typology helps the government and tourism industry to make crucial decisions on investment, product development, promotion, pricing, etc., and possibly assists them with forecasting future trends.

This paper also provided a comprehensive literature review on how the two important types of consequences of tourism (i.e. economic impact and cultural impact) were evaluated in the past. Due to the difficulty of quantifying cultural impact, a relatively small number of empirical studies of socio-cultural impact were found in the literature. This raised the issue that further studies are needed not only on investigating the economic impact of tourism, but also the cultural impact of tourism. The main findings summarized in this paper might be of great relevance for both tourism professionals and stakeholders working in the fields of cultural and sustainable tourism.

1. World Travel and Tourism Council (2010). Annual Report: Progress and Priorities 2009-2010, World Travel and Tourism Council, London. Retrieved from: http://www.wttc.org/bin/pdf/original_pdf_file/pandp_final2_low_res.pdf.

2. World Travel and Tourism Council (2006), World Travel and Tourism, Climbing to New Heights, World Travel and Tourism Council, London.

3. Mitsche, N., \& Strielkowski, W. (2016). Tourism e-services and Jewish heritage: a case study of Prague. European Journal of Tourism, Hospitality and Recreation, 7(3), 203-211.

4. Richards, G. (1996), Cultural Tourism in Europe, Wallingford: CAB International.

5. Silberberg, T. (1995). Cultural tourism and business opportunities for museums and heritage sites. Tourism Management, 16(5), 361-365.

6. Halkiv, L., \& Kulyniak, I. (2016). Agrohotels and rural tourism in the Ukrainian and Polish border regions. Czech Journa of Social Sciences, Business and Economics, 5(4), 6-13.

7. Vasylchak S, \& Halachenko, A. (2016). Theoretical basis for the development of resort services: regional aspect. International Economics Letters, 5(2), 54-62.

8. Swarbrooke, J., \& Horner, S. (2006). Consumer Behaviour in Tourism, Second Edition, Oxford: Elsevier, ButterworthHeinemann.

9. Chiabai, A., Platt, S., \& Strielkowski, W. (2014). Eliciting users' preferences for cultural heritage and tourism-related eservices: a tale of three European cities. Tourism Economics, 20(2), 263-277.

10. McKercher, B. (2002). Towards a classification of cultural tourists. International Journal of Tourism Research, 4, 29-38.

11. Ryan, C. (1998). Economic impacts of small events: estimates and determinants - a New Zealand example. Tourism Economics, 4(4), 339-352.

12. Sharpley, R. (1999). Tourism, Tourists and Society, $2^{\text {nd }}$ edition. Huntingdon, ELM

13. Simionescu, M., \& Strielkowski, W. (2017). brand loyalty and fashion marketing: a case study of Romanian youth. Marketing and Management of Innovations, (1), 25-31.

14. Čábelková, I., Abrhám, J., \& Strielkowski, W. (2015). Factors influencing job satisfaction in post-transition economies: the case of the Czech Republic. International Journal of Occupational Safety and Ergonomics, 21(4), 448-456.

15. Abrhám, J., Bilan, Y., Krauchenia, A., \& Strielkowski, W. (2015). Planning horizon in labour supply of Belarusian small entrepreneurs. Economic Research-Ekonomska Istraživanja, 28(1), 773-787.

16. World Tourism Organization (WTO) and European Travel Commission (ETC) (2005). City Tourism and Culture: The European Experience, Madrid, Spain 31.

17. Matarasso, F. (1997). Use or Ornanment? The Social Impact of Participation in the Arts. Comedia, the Round, Bournes Green, Stroud, Glos 31 .

18. Wall, G., \& Mathieson, A. (2006). Tourism: Economic, Physical, And Social Impacts, Pearson Education Limited.

19. Čábelková, I., Strielkowski, W., \& Mirvald, M. (2015). Business influence on the mass media: a case study of 21 countries. Transformation in Business \& Economics, 14(1), 65-75

20. Matarasso, F. (1999). Towards a Local Culture Index: Measuring the Cultural Vitality of Communities'. Comedia, Stroud Gloucester 31.

21. Cooper, C., \& Hall, C.M. (2008). Contemporary Tourism: An International Approach. First Edition, Oxford: Elsevier, Butterworth-Heinemann.

22. Smith, S.L.J. (1988). Defining tourism: a supply-side view. Annals of Tourism Research, 15, 179-190.

23. Chadwick, R. (1994). Concepts, definitions and measures used in travel and tourism research'. In J.R. Brent Ritchie and C. Goeldner (eds). Travel, Tourism and Hospitality Research: A Handbook for Managers and Researchers, $2^{\text {nd }}$ edition, pp.65-80. 
New York: Wiley.

24. Urry, J. (1995). Consuming Places, New York: Routledge.

25. Strielkowski, W., Tcukanova, O., \& Zarubina, Z. (2017). Globalization and economic integration: the role of modern management. Polish Journal of Management Studies, 15(1), 255-261.

26. Strielkowski, W., \& Čábelková, I. (2015). Religion, Culture, and Tax Evasion: Evidence from the Czech Republic. Religions, 6(2), 657-669.

27. Poon, A. (1993). Tourism, Technology and Competitive Strategies, Wallingford: CAB International.

28. Krippendorf, J. (1987). The Holiday Makers: Understanding the Impact of Leisure and Travel. Oxford: Heinemann Professional Publishing.

29. Horner, S., \& Swarbrooke, J. (1996). Marketing Tourism, Hospitality, and Leisure in Europe. International Thomson Business Press.

30. Roth, P., \& Langemeyer, A. (1996). Cultural tourism in Germany. In G. Richards, Cultural Tourism in Europe (pp.165182), Wallingford: $C A B$ International.

31. Strielkowski, W. (2016). Innovations in tourism marketing: operation Anthropoid in Prague. Marketing and Management of Innovations, (4), 106-112.

32. McKercher B., \& Du Cros, H. (2002). Cultural Tourism: The Partnership between Tourism and Cultural Heritage Management. Haworth Press, Binghamton, N.Y..

33. Small, K., Edwards, D., \& Sheridan, L. (2005). A flexible framework for evaluating the socio-cultural impacts of a (small) festival. International Journal of Event Management Research, 1(1), 66-77.

34. Young, R., Fernandez-Young, A., \& Parkin, J. (2008). Assessing the Economic Impact of Culture in Market Towns: Report on Findings. Culture East Midlands, East Midlands Cultural Observatory.

35. Getz, D. (1997). Event Management and Event Tourism. USA: Cognizant Communication Corporation.

36. Douglas, N., Douglas, N., \& Derrett, R. (eds.). (2001). Special interest tourism: context and cases. Australia: John Wiley and Sons.

37. Brougham, J.E., \& Butler, R.W. (1981). A segmentation analysis of resident attitudes to social impact of tourism. Annals of Tourism Research, 8(4), 569-590.

38. Belisle, F., \& Hoy, D. (1980). The perceived impact of tourism by residents. Annals of Tourism Research, 11(1), 83-101.

39. Sheldon, P., \& Var, T. (1984). Resident attitudes to tourism in North Wales. Tourism Management, 5, 40-48.

40. Keogh, B. (1990). Public participation in community tourism planning. Annals of Tourism Research, 17(3), 449-465.

Ц. Ван, PhD, викладач, Школа менеджменту, Університет Шаньдун (Шаньдун, Китайська Народна Республіка)

Економічний і культурний вплив маркетингу туризму

У цій статті досліджується, як моделювати причини і вимірювати наслідки культурного туризму, оцінюючи економічні та культурні наслідки, викликані культурними пам'ятками. У матеріалах поданий новий підхід, як до складання всебічного огляду літератури, так і до побудови методології і інструментарію для дослідження економічних і культурних наслідків маркетингу туризму. Результати та висновки цієї статті можуть бути корисні для зацікавлених сторін, політиків і професіоналів в галузі туризму, як в суспільному, так і в приватній сфрері. Крім того, ө статті проливається певне світло на роль інновацій у підвищенні економічного і культурного впливу туризму на маркетинг туризму. Ці результати можуть представляти певний інтерес, як для профресіоналів туристичного маркетингу, так і для маркетологів, які розробляють нові стратегії для збільшення впливу маркетингу туризму в старих і нових напрямках.

Ключові слова: туризм, культурний туризм, інновації, культурну спадщину, економіка туризму.

Ц. Ван, PhD, преподаватель, Школа менеджмента, Университет Шаньдун (Шаньдун, Китайская Народная Республика) Экономическое и культурное воздействие маркетинга туризма

В этой статье исследуется, как моделировать причины и измерять последствия культурного туризма, оценивая экономические и культурные последствия, вызванные культурными достопримечательностями. В материалах представлен новый подход, как к составлению всестороннего обзора литературы, так и к построению методологии и инструментария для исследования экономических и культурных последствий маркетинга туризма. Результаты и выводы этой статьи могут быть полезны для заинтересованных сторон, политиков и профессионалов в области туризма, как в общественной, так и в частной сфере. Кроме того, в статье проливается некоторьй свет на роль инноваций в повышении экономического и культурного воздействия туризма на маркетинг туризма. Эти результать могут представлять определенный интерес, как для профеессионалов туристического маркетинга, так и для маркетологов, разрабатывающих новые стратегии для увеличения воздействия маркетинга туризма в старых и новых направлениях.

Ключевые слова: туризм, культурный туризм, инновации, культурное наследие, экономика туризма.

Отримано 03.04.2017 p. 